Tatjana V. Mihajlović

Univerzitet u Banjoj Luci, Filozofski fakultet

Republika Srpska, Bosna i Hercegovina

Slaviša V. Jenjić ${ }^{2}$

Univerzitet u Banjoj Luci, Filozofski fakultet

Republika Srpska, Bosna i Hercegovina
UDC 37.014.1/.2 Komenski J.A.

37.014.53 Komenski J.A. doi: 10.19090/ps.2019.0.19-33

\title{
DRUŠTVENO-ISTORIJSKI KONTEKST, NAUČNI DOMETI I AKTUELNOST ŠKOLSKOG I NASTAVNOG PROCESA JANA AMOSA KOMESNKOG
}

\author{
Apstrakt
}

Jan Amos Komenski u pedagoškoj zaostavštini važi za jednog od najznačajnijih mislilaca u oblasti pedagogije. Iako je u vreme kada je živeo osuđivan zbog svojih stavova i uverenja koja je utkao u svoja dela, važi za mislioca svoga vremena koga je krasila pedagoška strast sa kojom je delovao u oblasti teorije i prakse vaspitanja $i$ obrazovanja. Renesansni način mišljenja došao je do izražaja u pedagoškim idejama Komenskog koji se zalagao za napuštanje jednostranosti starih sholastika, za obrazovanje čoveka za nebesko, ali i za zemaljsko carstvo. U želji da prevaziđe intelektualnu jednostranost stare škole, njegova pansofijska koncepcija vaspitanja i obrazovanja doprinela je kvalitenijem sticanju znanja, usvajanju veština i navika. Nova škola želi da implementira naučna saznanja u vaspitno-obrazovni proces, podstiče aktivnost $i$ samoaktivnost učenika.

Cilj našeg rada jeste da ukažemo na naučne domete i aktuelnost školskog $i$ nastavnog procesa Komenskog. Za potrebe rada primenjena je metoda teorijske analize $i$ istorijska metoda sa tehnikom analize sadržaja. Proučavanje primarnih i sekundarnih izvora zahvaljujući primenjenim metodama, eksplicitno ukazuje da je rad Komenskog bio i ostao predmet proučavanja i istraživanja s obzirom na pregršt korisnih ideja, misli, saveta i uputstava na kojima današnji pedagozi i praktičari temelje svoj rad. Pored epohalnog dela Velike didaktike, knjiga Orbis Sensualium Pictus ukazuje na neophodnost povezivanja čulnih utisaka sa aktivnostima učenika. Predstavlja jednu vrstu metodičkog udžbenika u kojoj se na inovativan način učenicima pruža mogućnost da efiksno usvoje nastavne sadržaje.

\footnotetext{
${ }^{1}$ tatjana.mihajlovic@fff.unibl.org

${ }^{2}$ slavisa.jenjic@,ff.unibl.org
} 
U zaključku autori ukazuju da u prošlosti uvek nalazimo i deo savremenosti koja se tiče Komenskog i njegovih saznanja.

Ključne reči: pedagoški realizam, pansofijska koncepcija vaspitanja, školski $i$ nastavni proces.

\section{Uvod}

Vaspitanje i obrazovanje tokom svoje istorije prošlo je izuzetno dug put razvoja, isto toliko koliko i razvojni put ljudskog društva (Avdijev, 1952). Ovaj razvojni put traje toliko koliko i traženje odgovora na mnoga pitanja o čoveku i njegovom razvoju koja su uvek iznova postavljana u vekovima postojanja i razvoja ove delatnosti (Мединский, 1947). Vekovi trajanja poučavanja čoveka su u isto vreme bili i vekovi njegovog nemirenja sa postojećim, dostignutim, ali i konstantnim traganjem za novim rešenjima koja bi u ovoj ljudskoj delatnosti značila napredak, preobražaj, obnovu svega postojećeg sa ciljem unapređenja kvaliteta čovekovog života.

$\mathrm{U}$ istorijskoj prošlosti značajne promene u sferi obrazovanja i vaspitanja desile su se u vreme humanizma i renesanse. Renesansni način mišljenja došao je do izražaja u pedagoškim idejama humanista koji se zalažu za napuštanje jednostranosti starih sholastika, za obrazovanje čoveka „za nebesko, ali i za zemaljsko carstvo“ (Despotović, 1902: 130). Humanizam uzdiže vrednost ličnosti deteta, koju u vaspitanju treba poštovati i težiti antičkom idealu - kalokagatiji (Cenić i Petrović, 2012: 110-111). Humanizam i reformacija su srodni momenti radikalnog istorijskog i kulturnog obrta koji su čoveka vratili ovome svetu, razotkrili mu njegove lepote, opasnosti i probleme, izazvali žudnju za naukom (Despotović, 1902; Žlebnik, 1970). Tako je paradigma obrazovanja renesanosnog perioda zasnovanog na prosvetiteljskoj filozofiji, bila suprotna srednjovekovnom obrazovanju utemeljenom na saznajnom determinizmu, krutosti, egalitarizmu, predvidljivosti i normiranosti (Mihajlović, 2019).

Ideje humanista obuhvataju širok front filozofskih, posebno empirističkih, racionalističkih i materijalističkih pristupa. Podrazumevaju zajednički pogled na određene vrednosti kao što su lične slobode, građanska jednakost, vera u razum, obrazovanje, prosvećenost, naučno mišljenje (Vlahović, 2001: 21-23). Kao izraz opšteg napretka saznanja, period humanizma i renesanse predstavlja age des lumieres (novu svetlost), nasuprot srednjovekovnom mraku, ideji da je ancilla theologiae (nauka u službi teologije) (Ilić i Mihajlović, 2016: 100-101). Humanističke ideje prožimale su učenja pedagoških klasika poput Johana Hajnriha Pestalocija (Johann Heinrich Pestalozzi), Jana Amosa Komenskog (Jan Amos Komenský), Johana Fridriha Herbarta (Johann Friedrich Herbart) i drugih. Nagoveštaje mnogih teorijskih saznanja koja se nalaze $u$ osnovi savremenih strategija nastave i učenja nalazimo u učenjima ovih pedagoga. Za naš rad posebno su interesantna shvatanja Komenskog koji važi za najvećeg pedagoškog utemljivača i mislioca, idejnog tvorca pedagoškog sistema (Cipro, 1991; Glenn, 
2018; Lang, 1965; Lukaž \& Munjiza, 2014; Vukasović, 2003).S pravom se možemo složiti sa Pijažeom da je Komenski autor od pre gotovo četiri veka, koji se i danas smatra inovativnim, modernim i značajnim za pedagošku teoriju i praksu (Piaget, 1993). Iako je u vreme kada je živeo osuđivan zbog svojih stavova i uverenja koja je utkao u svoja dela, važi za mislioca svoga vremena koga je krasila pedagoška strast sa kojom je delovao u oblasti teorije i prakse obrazovanja (Glenn, 2018; Maviglia, 2016). Glavna ideja vodilja i pokretač njegovog celokupnog pedagoškog rada su slabe obrazovne mogućnosti Komenskog (Glenn, 2018), s obzirom da je prvu obrazovnu šansu dobio tek sa šesnaest godina. Srednje obrazovanje nastavlja u Latinskoj školi, nakon čega završava Univerzitet u Hajdelbergu (Stroope, 2005; Zaninović, 1988).

Po svojim životnim opredeljenjima važio je za čoveka optimistu. Verovao je u regenerišuću moć obrazovanja i smatrao da se obrazovanjem mogu poboljšati uslovi čovečanstva (Dobinson, 1970; Gundem, 1992; Lang, 1965; Maviglia, 2016). Želio je pomoću pansofije ukloniti sve nesporazume i poroke među ljudima i narodima, uspostaviti opšte razumevanje, slogu i mir. Imajući u vidu navedeno, Jan Amos Komenski u svojoj zaista obimnoj misaonoj riznici ukazao je na mnoga shvatanja vezana za: potrebu i snagu vaspitanja i njegove duboko plemenite i preobražavajuće funkcije, optimističko verovanje u mogućnosti razvoja čoveka, demokratski stav o neophodnosti organizovanja škola i njene vaspitne funkcije, potrebu kontinuiranog, permanentnog sistema vaspitanja i obrazovanja, metodička pitanja. Njegov pedagoški realizam imao je za cilj prevazilaženje slabosti tradicionalne škole i njene intelektualne jednostranosti. Nova škola Komenskog želi da implementira naučna saznanja u vaspitno-obrazovni proces, podstiče aktivnost i samoaktivnost, obrazuje čoveka za nebesko, ali i za zemaljsko carstvo.

\section{Pansofijska koncepcija vaspitanja}

Uticaj renesansne pedagogije i renesansnog životnog optimizma (utopijskog socijalizma), zatim demokratskih težnji tadašnjih verskih sekti i Bekonove filozofije u velikoj meri uticali su na Komenskog i njegove pedagoške poglede. Za razliku od srednjovekovnog shvatanja čoveka koji je značio samo „stvorenje opterećeno gresima“ (Žlebnik, 1970: 59), Komenski iznosi novo, realnije shvatanje o čoveku. Njegov čovek je živ i divan i pored toga što je najviši vaspitni cilj video u sticanju večnog blaženstva na drugom svetu (Isto). Shvatanje čoveka kao najodličnije stvorenje (Komenski, 1997), koga vaspitanje formira u celokupnosti njegovog bića (Isto) da bi ga pripremilo za večni život, životnije je, plemenitije od srednjovekovnog, a samim tim otvara mogućnost konkretnog učešća u sistemu vaspitanja i obrazovanja.

Prema srednjovekovnoj hrišćanskoj ideologiji, telo je tamnica za dušu, gde crkva povezuje celokupno vaspitanje svojim religioznim, teološkim shvatanjima (Zaninović, 1988; Žlebnik, 1970). Za razliku od stanja ljudskog duha i njegove naučne misli u epohi civitas dei, nova renesansna misao u centar svojih razmišljanja stavlja čoveka 
shvaćenog kao homo universale, suprotstavljajući ga dotadašnjem shvatanju čoveka u božijoj državi. Stoga, priprema za večni život čoveka za Komenskog sastoji se u usvajanju nauke, morala i verskih osećanja, a klica svega, za razliku od srednjovekovnog shvatanja, je u čoveku. Čovek je najviši, najbezuslovniji i najizvrsniji stvor, savršeno biće, harmonija tela i duha, a vaspitanje ga izgrađuje i oblikuje u celini njegovog bića (Komenski, 1997: 49-50). Zahteva da se vaspitanje prilagodi zakonima prirode, te je najopštiji princip Komenskog, na kome je izgradio zgradu svoje pedagogije, utemeljen na ideji da vaspitanje treba da bude u skladu sa spoljašnjom prirodom, da vodi računa o prirodi deteta, da na njoj izgrađuje i u skladu sa njom podstiče razvoj deteta (Žlebnik, 1970: 59-60). Ovaj princip je realniji, životniji, aplikativniji za razliku od srednjovekovnog. Predstavlja prirodni izraz procenjivanja i poznavanja prirode, prepoznatljiv zahvaljujući novom načinu mišljenja renesansnog perioda. Posebne zasluge za ovo ima Ludvig Vives (Ludovicus Vives) koga Komenski navodi u kontekstu njegovog razmišljanja da ništa drugo nije preostalo hrišćaninu nego da se čovek vrati svojoj prirodi i u svoje rođeno pravo iz koga ga je đavo isterao (Komenski, 1997: 61-62). Ovaj princip skladnosti vaspitanja i prirode prihvatili su mnogi klasici pedagogije.

Može se kazati da vaspitanje za Komenskog predstavlja osnovni faktor i sredstvo kojim se nedostaci u ljudskom životu mogu otkloniti. Čovek je savršeno biće, harmonija tela i duha, a vaspitanje ga izgrađuje i oblikuje, priprema za ovozemaljski i večni život (Isto). Sam cilj vaspitanja podrazumeva da stvori upotrebljive, korisne, srećne i dobre ljude, koji bi u sličnosti s Bogom gledali najviše čovečansko savršenstvo (Isto). Vaspitnje mora poznavati zadatak, sredstva i oblik discipline, dok su disciplinska sredstva sasvim realna i svrsishodna. Jan Amos Komenski je vrlo oprezan u pogledu izricanja disciplinskih mera, ali je i protiv permisivnog stava koji zanemaruje disciplinu. Zalaže se za brižljiv, čovečan, ali i dosledan odnos prema deci, u kom se zahvaljujući pansofijskoj koncepciji vaspitanja poštuje njihova ličnost.

Upravo je Komenski iznoseći svoje stavove o vaspitanju osetio opasnosti srednjovekovnih jednostranih pristupa čoveku i sukoba koje je razrešavao pansofijskom mudrošću, celovitim i jedinstvenim poimanjem sveta i života, spoznavanja i etičkog vrednovanja, sintezom naučnih, ali i filozofskih, etičkih i religijskih postignuća. Njegova pansofija odnosila se na sveopštu mudrost, enciklopediju znanja, realan pogled na čoveka, svet i život. Sastoji se od jedinstva prirodnog razvoja i sadržaja, ali i metode temeljitog učenja i vaspitanja svih svemu (Vukasović, 2003). Kao takvu ugradio je u svoje pedagoško stvaralaštvo, vezano za univerzalnu mudrost kojoj je težio. Zapravo Komenski ukazuje na četiri bitna elementa na kojima se temelji pansofija, a to su univerzalna knjiga, univerzalna škola, univerzalni koledž i univerzalni jezik (Maksimović, Osmanović i Milanović, 2018). Zato je sveobuhvatna pansofijska koncepcija vaspitanja bila aktuelna u doba Komenskog s obzirom na vaspitni proces koji se svodio na sticanje znanja koje nije moglo osigurati negovanje i razvijanje svih pozitivnih ljudskih osobina i sposobnosti. Njegova pansofijska koncepcija vaspitanja osigurava kvalitetnije sticanje znanja, usvajanje veština i navika zahvaljujući efikasnoj organi- 
zaciji celokupnog vaspitno-obrazovnog procesa. Na osnovu shvatanja Komenskog, čovek je savršeno biće, harmonija duše i tela, a vaspitanje ga izgrađuje i priprema za ovozemaljski život, upravo zahvaljujući mudrosti, kao i jedinstvenom poimanju sveta i života, naučnih dostiguća. Ovako sveobuhvatna pansofijska koncepcija vaspitanja bila je vrlo aktuelna.

Čovek postaje čovekom zahvaljujući vaspitanju. Vaspitanje je proces očovečenja, pretpostavka i osnova čovečnosti. Njime se stiče obrazovanost, krepkost i pobožnost (Komenski, 1997). Za Komenskog nesretno je ono obrazovanje koje ne prelazi u vrlinu i pobožnost, a učenost nije ništa bez morala. Onaj ko napreduje u nauci, a nazaduje u moralu - više nazaduje, nego napreduje (Isto). S tog gledišta, on je obrazovanje opisao kao opšte dobro svih ljudi (Isto). Obratio se onima koji imaju moć u nekoliko država, crkvenim školama i porodicama pozivajući ih da primene otkrića i preporuke pedagogije, kako bi trebalo da bude „manje neznanja, konfuzije i neslaganja, ali više svetlosti, reda, mira i tišine“ (Dobinson, 1970: 36). Škole treba da obrazuju i ljudski oblikuju čoveka (Komenski, 1997: 79-80). Smatra da ako bi svi ljudi bili učeni istim stvarima u svim aspektima, bili bi mudri. Mudrost koju bi tako stekli prožela bi njihovu svest, jezik, srce i ruke, a oni bi se ujedinili u pansofijsku zajednicu (Kamenov, 2006: 85-86). Pansofijska pedagoška koncepcija proizašla je iz potrebe efikasnog vaspitanja i obrazovanja Komenskog. Zasnovana je na demokratskom i humanom principu da se vaspitaju svi bez izuzetka, o svemu što je neophodno za život, i u svemu što razvija i usavršava čoveka - omnes, omnia, omnino (svi, sve, svemu).

Jan Amos Komenski uočio je slabosti srednjovekovnog školstva, zasnovanog na didaktičkom intelektualizmu, zanemarenoj vaspitnoj funkciji škole. Kritikovao je jednostrane intelektualističke orijentacije (Vukasović, 2003: 95-96) i zahtevao da vaspitanje bude sveobuhvatno, da se vaspitava čitav čovek, da ljudi zaista budu ljudi, a škole radionice čovečnosti, „zborišta omladine“ (Komenski, 1997: 83) u kojima treba obezbediti skladno ostvarivanje ratio, oratio, operatio (mišljenja, govorenja i delovanja). Ovaj inovativan stav Komenskog može se postići ako vaspitna nastojanja u školi budu usmerena da ljude čine mudre duhom, radom razborite i srcem pobožne (Isto). Jan Amos Komenski ovim jasno ističe pansofijsku koncepciju škole, koja u sebi podrazumeva vaspitnu komponentu, potpuno zanemarenu u srednjovekovnom periodu. Možda je to slučaj i danas.

Današnje škole su, u odnosu na vreme kada je živio Komenski, značajno napredovale u smislu organizacije rada, didaktičko-metodičke realizacije nastavnih časova i kreativno-stvaralačkog angažovanja učenika u radu. Zasluge za to mogu se pripisati viziji i idejama koje je imao Komenski. Svojevremeno je istakao da nastavno gradivo treba pažljivo izdeliti na razrede, tako da ono što dolazi ranije svuda utire put i pali buktinje onome što dolazi kasnije (Isto). Iako podložan kritikama, razredno-predmetno-časovni sistem rada aktuelan je u mnogobrojnim školskim sistemima i danas. I dok je tako vrediće još jedno pravilo koje je postavio, a to znači da vreme valja podeliti tačno tako da svakoj godini, mesecu, danu i času pripadne određeni zadatak (Isto). 
Istina je da postoje škole drugačije organizacije i rada, ali, i u takvim školama nisu isključeni principi rada utemeljeni na paradigmi Komenskog. Njegova postavka da se u detinjstvu upravlja primerima, a ne propisima, aktuelna je i interesantna za savremene metodike, posebno one koje se odnose na mlađi osnovnoškolski uzrast. Ovo se može posmatrati iz dva pravca. Prvi, nastavnik treba da je primer deci. Drugi pravac posmatranja jeste metodički, učenicima u nastavi donositi iz prirode i pokazivati primerke onoga što je sadržaj učenja. Jer, Komenski za učitelja postavlja zlatno pravilo da se pred čula ima iznositi što god se može (Jenjić i Dragić, 2017). Slikovito je to opisao rečima: što je vidljivo - čulu vida, što se čuje - čulu sluha, što mirišemo - čulu mirisa, što ima ukus - čulu ukusa, što je opipljivo - čulu pipanja (Komenski, 1997). Savremeni pedagozi, didaktičari i metodičari ukazuju na značaj ovakvog pristupa u nastavi.

\section{Sistem vaspitanja i obrazovanja za Jana Amosa Komenskog}

U duhu svoje pansofijske misli Komenski usmerava vaspitna nastojanja škole u smeru izgrađivanja čoveka u kome njene sadržajno-strukturalne komponente skladno povezuju telesne sposobnosti i zdravlje, duhovono bogatstvo, intelektualne sposobnosti, istinoljubivost i samostalnost, moralnu snagu i dobrotu, estetski smisao za skladno i lepo, kulturu rada, efikasnost i stvaralaštvo. Smatra da efikasnim vaspitanjem treba izgrađivati zdrave, sposobne i čestite ljude, ljude čista uma, spretnih ruku, snažne volje i čiste savesti, ljude koji će biti nosioci celokupnog društvenog, kulturnog i moralnog napretka. Ovako shvaćena funkcija vaspitanja Komenskog neposredno je proistekla iz nasleđenog Kvintilijanovog optimističkog verovanja u mogućnosti razvoja čoveka, koji je po njemu vrhunac božjeg stvaranja i kruna njegove slave (Komenski, 1997). U čovekovu prirodu duboko je usađena težnja za saznanjem, koja nema ni kraja ni granica, ni na nebu ni drugde izvan neba: on se penje u nebesa nad nebesima baš kao što silazi u provaliju nad ponorima (Isto). Ove mogućnosti čoveka pretvaraju se u stvarnost samo učenjem i obrazovanjem, jer za Komenskog niko ne može postati čovek ako ga ne poučimo onome što čoveka čini čovekom (Isto). Otuda i odlučna izjava da je svima koji su rođeni neophodno obrazovanje, jer treba da budu ljudi, a ne divlje zveri (Isto). Najzad, veru da svako može do svoje mere razviti sposobnosti, Komenski je izrazio i dobro poznatim rečima ,teško da će se naći tako prljavo ogledalo koje ne bi bar kako-tako primalo slike“" (Komenski, 1997: 177).

U ovim izrazito humanim mislima Komenskog nalaze se koreni njegovog demokratskog stava o neophodnosti efikasnog obrazovanja i vaspitanja, za što su potrebne škole. Vođen Luterovom idejom, on je zahtevao da se škole podižu u svim gradovima, palankama i selima za obrazovanje „sve omladine oba pola, bez obzira da li su siromašni ili bogati, kako bi se poučavali u nauci, vrlini i pobožnosti“ (Isto, 91). Ova demokratska želja za efikasnim vaspitanjem i obrazovanjem u suprotnosti je sa svim dotadašnjim školama, posebno onim jezuitskim koje su primale samo društvenu elitu. Jan Amos Komenski takođe se oštro borio protiv elitističke latinske škole humanista 
u želji za demokratskom školom, dobro organizovanom koja treba da implementira društveno-korisne, praktične veštine, kao i naučno znanje o prirodnom okruženju. Njegov ideal demokratskog humanizma dostignut je tek u budućnosti, izvan ograničenja novonastalog kapitalističkog sistema. Bio je to utopijski ideal, s obzirom na to da je Komenski osetio potrebe narodnih masa dovoljno duboko da savlada uski elitistički pogled koji je dolazio iz redova vladajuće klase.

U želji za humanom školom kojoj je težio, njegov utopistički ideal otišao je daleko, s obzirom na verovanje da će reforma obrazovanja dovesti do reforme sveta. To je razlog da obrazovanje shvata kao opšte dobro svih ljudi (Dobinson, 1970: 3435). Takođe, u izreci posvećenoj negovanju talenta (De cultura ingeniorum oratio) Komenski je detaljno predstavio i socijalne prednosti obrazovanja značajne za državu. Naglasio je da prosvetljenje nacije podrazumeva kako najbolje iskoristiti plodove zemlje. Zapravo u Pangresiji Komenski iznosi svoju ideju o ulozi obrazovanja za unapređenje međunarodnih odnosa, za opšti mir i dobrobit svih ljudi (Isto). Zar je potrebno naglašavati kakvo je futurološko značenje imao ovaj njegov zahtev ne samo u vremenu kada je izrekao, već kakvo značenje ima i danas za naše prilike?

Jan Amos Komenski je imao istorijsku zaslugu za organizaciju školstva i nastave (Žlebnik, 1970). Zamišljao je svet kao lavirint, u kom su se našle i škole. Ova metafora, duboko ukorenjena u srednjovekovnim tradicijama mistike i asketizma, morala je imati neki izlaz. Uporno i hrabro Komenski je gledao na izlaz iz lavirinta kao na otvorene ravnice koje treba da pokažu put čoveku u lavirintu loših škola (Dobinson, 1970). U tom svom razmišljanju o sistemu obrazovanja i vaspitanja ispoljio je jedan našem vremenu veoma blizak pedagoški zahtev. Zalagao se za kontinuirano, permanentno obrazovanje koje treba da počne rođenjem i traje do kraja života. Ova njegova koncepcija kontinuiranog, celovitog i jedinstvenog sistema vaspitanja i obrazovanja, bila je ideja vodilja u ostvarivanju našeg savremenog, demokratskog i jedinstvenog školskog i vaspitnog sistema - od društveno organizovanog predškolskog vaspitanja do razvijenog sistema vaspitanja i obrazovanja (Vukasović, 1986: 171-172). Dobro organizovan sistem vaspitanja i obrazovanja trebao bi da implementira društveno korisne praktične veštine, kao i naučna znanja o prirodnom okruženju. Tako je za Komenskog čitav život učenje (Komenski, 1997), te izdvaja više međusobno povezanih perioda, a svakom od tih perioda ili etapa predstavlja svojevrsnu školu. Takvih škola po Komenskom je sedam počevši od schola geniturae (škola pre rođenja ili škola rođenja), schola infantiae (škola detinjstva), pa sve do schola senii (škole starosti) (Tešić, 1970: 4-5).

Velika zasluga pripada Komenskom što je utvrđujući periode celovitog i jedinstvenog sistema vaspitanja i obrazovanja, prihvatio evidentna saznanja o značaju perioda detinjstva u razvoju ličnosti. Na temelju takvih saznanja s pravom bismo mogli reći da je naučno konstituisao jedno područje pedagoškog rada. To je materinska škola (materinsko krilo), za koju je napisao i pedagoški priručnik Informatorium za materinske škole. Uprkos vremenu kada je napisana i danas je rado čitana knjiga. Sadrži niz vrednih saveta i sugestija u pogledu sadržine i metodike pedagoškog rada s 
decom predškolskog uzrasta. Predstavlja prvo teorijsko delo iz oblasti vaspitanja u kome Komenski ukazuje da su deca „najdragoceniji dar i blago“ (Komenski, 1946: 15), kome smo dužni da ukazujemo istu ljubav i poštovanje kao sami sebi, a bavljenje njima najveća je radost (Isto,16-17). Može se kazati da je u ovom pogledu Komenski inovativan. Donosi novi senzibilitet odnosa prema detinjstvu, koji je radikalno suprotan srednjovekovnom, gde se „,vaspitna strategija zasnivala na nasilnoj, demagoškoj paroli“" (Spevak, 2003: 83). Jan Amos Komenski ukazuje da je odnos prema deci, odnos prema budućnosti, s obzirom na to da roditelji nisu odgovorni samo da obezbede biološki razvoj svoje dece već treba da se postaraju da im „ukrase misli i dušu“, kako bi kada porastu, mogli „razumno i korisno da prožive svoj zemaljski vek“ (Komenski, 1946: 17-18). Zato vaspitanje dece treba da započne što pre, još u prenatalnom periodu, zatim u materinskoj školi, s obzirom na to da je kasnije teško ispravljati drvo koje ukrivo izraste (Isto, 21-22). Preporučuje zapravo da sve počne u pravo vreme, što znači da ne treba pokušavati ubrzati razvoj niti odgađati delovanje na njega. On izlaže celokupni vaspitni program u materinskoj školi za period od rođenja do polaska dece u školu koji podstiče sve komponente razvoja ličnosti. Koncepcija programa zasnovana je na potrebi da se sva deca vežbaju svemu što im je neophodno za život, a to su "vera i pobožnost, čestitost, znanje jezika i veština" (Mihajlović, 2014: 44).

Takođe, pedagoški značaj imaju i razmišljanja Komenskog o pedagoškoj koncepciji i organizaciji škole dečaštva (osnovne, narodne, elementarne škole), čije je pedagoške probleme razrađivao u svojim poznatim spisima (Didactica magna, Orbis sensualim pictus, Pampedia - Panskolia). Po njegovoj zamisli to je šestogodišnja škola za opšte elementarno obrazovanje, u kojoj učenici na maternjem jeziku treba da stiču osnovnu pismenost i određena znanja iz matematike, muzike pa sve do geografije i privrede (zanata). To je škola koju treba da završe svi, bez obzira kom će se pozivu posvetiti i čime će se kasnije u životu profesionalno baviti, ili ako kažemo njegovim rečima, njegova pansofijska koncepcija škole maternjeg jezika podrazumeva školu čovečnosti, u kojoj se staraju duhom mudri, radom pametni i srcem pobožni i moralni ljudi (Komenski, 1997). Mislimo da ovakav koncept osnovne (opšte-obrazovne) škole ima istinsko revolucionarno značenje i da se s pravom Komenski smatra idejnim tvorcem moderne osnovne škole. I materinska i osnovna škola (škola maternjeg jezika) predstavljaju samo određene stepene $\mathrm{u}$ jedinstvenom lancu obrazovanja s obzirom na to da se na njih nastavljaju takođe šestogodišnja latinska škola (gimnazija), zatim akademija. Pored ovih škola Komenski je predvidio školu za školu u kojoj bi radili naučnici sa zadatkom da unapređuju sve škole. Može se slobodno kazati da je on začetnik ideje otvaranja instituta za istraživanje pedagoške problematike (Kačapor, 2003: 89-90). Iz ovoga sledi zaključak da je Komenski institucionalno obrazovanje protezao do dvadesetčetvrte godine starosti, posle koga bi trebalo da dođe slobodno obrazovanje, odnosno samoobrazovanje. Ovako organizovan školski sistem Komenskog doprinosio je kvalitetnijem sticanju znanja u odnosu na dotadašnje srednjovekovne sisteme, usmerene na nastavne programe septem artes liberales(sedam slobodnih veština) u okviru triviuma i kvadriviuma. 


\section{Škola - radionica čovečnosti}

Jan Amos Komenski je srednjovekovnu školu u kojoj se učenje svodilo na memorisanje gotovih, tuđih znanja nazivao mučilištem, tvrdeći da se u njoj nad duševnim sposobnostima učenika vrši nasilje (Komenski, 1954: 70). Škola učenika silom kljuka znanjima prisiljavajući ga da pamti i govori samo tuđa mišljenja o stvarima (Isto,71-75). Konstatuje da nastavnici ne uče učenike da se razvijaju iz sopstvenog korena, već ih navikavaju da se ukrašavaju grančicama ubranim jedino s drugog drveća (Isto,135-136). Tako, umesto da raskopavaju izvor razumevanja koji je „sakriven u njima, oni ih napajaju tuđim potočićima“ (Isto,135). Za Komenskog znanja tako poučavanih učenika svode se na prazne ljudske reči, dosadna „papagajska brbljanja, plevu i maglu mišljenja“ (Isto,71). Ovako jednostranoj školi Komenski suprotstavlja školu koju naziva „radionicom čovečnosti“ (Isto,65). U njoj se nastavnici koji dobro znaju veštinu poučavanja brinu da učenici uistinu postanu ljudi. Kako? Nastavom koja učenicima omogućava i pomaže da do znanja dolaze što samostalnijom vlastitom misaonom aktivnošću.

Za Komenskog učenik mora sam donositi sud o stvarima, što zapravo ukazuje da oni efikasnije usvajaju znanja: umesto nastave upućene na memorisanje, zamenjuje nastavom upućenom prvenstveno na rasuđivanje. Pri tom posebno insistira na otkrivanju uzročno-posledičnih odnosa. Znati za Komenskog podrazumeva poznavati stvari po uzročnosti, te se stoga sve mora i učiti pomoću uzroka (Isto,140). S tim u vezi u Velikoj didaktici zahteva da se u školi učenje sa da zameni sa učenjem zašto „kako bi se učenici navikavali da zapažaju uzroke i posledice“ (Isto,255). Uz napomenu da je prosto neverovatno kako se učenicima otvaraju oči kada nauče da samostalno ,jedno objašnjavaju drugim“ (Isto,140). Za razliku od sholastičke nastave, u nastavi za koju se zalaže Komenski nema mesta verbalizmu i šablonizmu. Smatra da nikome ne treba dopustiti da govori ono što ne razume, a da se to ne bi dešavalo reči se moraju organski vezivati za stvari. To je smisao sugestije Komenskog da se „reči uče samo u vezi s predmetima“"(Isto,161). Po svemu sudeći Komenski je znao da sadržajne reči ne služe samo za saopštavanje misli, već da učestvuju i u njihovom formiranju, pa je sugerisao da se pri učenju što češće primenjuje kazivanje naučenog. Ovo aktivno učenje za Komenskog je namerno, svesno, planirano, sistematično, zahvaljujući u velikoj meri njegovim metodičkim iskustvima.

Metodika nastave za Komenskog podrazumeva poznavanje gradiva, ciljeva nastave koji su bili specifični za svaku etapu školskog sistema, efikasne postupke i oblike rada koji su u velikoj meri doprinosili ovoj vrsti aktivnog znanja. Za aktivno učenje vezuju se interesovanja učenika. Kao sinonim za interesovanja Komenski često koristi termine želja za učenjem, zaokupljenost duha, raspoloženje za učenje i slično. U tom kontekstu jasno ukazuje „na vezu između interesovanja i motivacije“ (Vučinić, 2011: 695). Stoga predlaže niz metodičkih postupaka za buđenje radoznalosti učenika, poput onih da je učenicima potrebno objasniti značaj onoga što uče, pa sve do toga kako 
olakšati učenje i učiniti ga prijatnijim (Kamenov, 2006: 85-86). Smatrao je da se učitelji „slabo brinu o učenicima, jer ih gone na nauke preko njihove volje“ (Komenski, 1954: 118). Stoga predlaže očiglednost koja podrazumeva celovito čulno zapažanje (percipiranje) predmeta radi prikupljanja određenog fonda činjenica na temelju kojih se formiraju jasne predstave o tim predmetima (Branković i Ilić, 2011). Čulna iskustva često su izvor saznanja u nastavi, te se Komenski rukovodi ovim principom koji je nazvao i zlatnim pravilom nastave. Zahtevajući da se sve predaje uz učešće čula, Komenski očiglednost nije smatrao ciljem već sredstvom dobre nastave. Za njega je ona pretpostavka misaone aktivizacije učenika, jer znanje počinje od čula, a na to se nadovezuje razmišljanje, stvaranje pojmova (Komenski, 1954: 123). Dakle, očiglednost, koju je on svodio na neposredno opažanje nije nužna radi očiglednosti, već radi omogućavanja učenicima da misle, da misaonom obradom čulnih iskustava stiču naučna saznanja. Zahvaljujući njegovoj knjizi Orbis Sensualium Pictus koja je bila edukativna slikovnica i prvi udžbenik očigledne nastave (Kamenov, 2006; Žlebnik, 1965), Komenski je upravo doprineo da učenici misaonom obradom čulnih iskustava stiču naučna saznanja. Smatrao je da sa razgledanjem ove edukativne knjige treba započeti još u predškolskom uzrastu (Komenskèho, 1932); zasnovana je na vizuelnom doživljaju, angažuju se čula, a razlog tome je što se u ranom periodu dečijeg uzrasta apstraktna znanja teško usvajaju (Isto). I pored toga što je prošlo više od tri veka od izlaska ove knjige, Orbis Sensualium Pictus se smatra jednom od spomenika pred-pedagogije. Predstavlja jednu vrstu metodičkog udžbenika u kojoj se na inovativan način daje mogućnost učenicima da efikasno usvoje nastavne sadržaje. Orbis Sensualium Pictus još uvek je retka i tražena knjiga, ali i model za sastavljanje današnjih savremenih udžbenika (Čuma, 1991: 607). Svako učenje mora početi čulima kako bi se ostvarilo razumevanje, što potvrđuju i filozofski principi Komenskog svrstani u pet kategorija počevši od okruženja, učenja koje uključuje čula, socijalizacije pa sve do verske obuke (Lang, 1965).

Da bi se efikasno usvojila znanja, formirale veštine i navike, razvijale stvaralačke sposobnosti i druga pozitivna svojstva ličnosti Komenski ukazuje na važnost metoda u nastavi. Želju za aktivnim učenjem može izazvati i sam metod rada (Komenski, 1954: 119), imajući u vidu da je najpouzdanije motivaciono sredstvo onaj način realizovanja nastave koji učenike misaono angažuje i intelektualno osamostaljuje. Smatra da je svakom ko želi saznati suštinu neke nauke važno da ima bistro oko, da se predmeti približe, da bude prisutna pažnja i da odgovarajućom metodom pružamo jedno za drugim ono što učenik treba da posmatra, jer će tada sve shvatiti pouzdano i brzo. Tako je demokratski postulat zajedničkog obrazovanja Komenskog zahtevao takve metode na osnovu kojih bi se postigli fer rezultati koje mogu postići svi učenici. Razvijao je i predlagao induktivni pristup u učenju, zahtevajući tome da se ne koristi analitička, već sintetička metoda u učenju (Jůvová \& Bakker, 2015). Njegova ideja učiti u skladu sa zakonima prirode, postepeno savladati svaki nastavni sadržaj zahvaljujući metodičkim uputstvima i sve to potkrepiti čulima, pravila su uspešnog obrazovnog i vaspitnog 
procesa (zasnovanog na pansofijskoj koncepciji) koje možemo proizvesti i nastojati da primenimo u njegovoj školi, radionici čovečnosti.

\section{Zaključak}

Jan Amos Komenski i njegovo delo predstavljaju jedan od najvrednijih doprinosa riznici pedagoške nauke. Najveći je mislilac u istoriji pedagogije, glasnik naprednih misli i težnje epohe humanizma, pokretač vaspitnih i školskih reformi, tvorac vaspitnog i obrazovnog sistema. Više nego bilo koji drugi pedagog spoznao je društvene potrebe svoga vremena zahvaljujući pansofijskoj koncepciji vaspitanja, kojom je nadmašio društveno-istorijski kontekst u kome je živio. Njegova pansofija podrazumevala je sveopštu mudrost, enciklopediju znanja, realni pogled na čoveka, svet i život. U duhu svoje pansofijske misli Komenski usmerava vaspitna nastojanja škole u smeru izgrađivanja čoveka u kome njene strukturalne komponete skladno povezuju telesne sposobnosti i zdravlje, duhovno bogatstvo, intelektualne sposobnosti, istinoljubivost i samostalnost, moralnu snagu i dobrotu. Pedagoški realizam Komenskog imao je za cilj prevazilaženje slabosti tradicionalne škole i njene intelektualne jednostranosti. Želio je novu školu koja treba da implementira naučna saznanja u nastavni proces, podstiče aktivnost i samoaktivnost, obrazuje čoveka za nebesko, ali i za zemaljsko carstvo.

Veličanstveni duh Komenskog nakon gotovo četiri veka je aktuelan i podsticajan i danas. Sa nepredvidivom tačnosti, već u sedamnaestom veku naznačio je napredne pedagoške težnje nove epohe i široko zacrtao put razvoju školstva, nauke o vaspitanju za budeće vekove. Njegove vizionarske ideje vezane za optimističko verovanje u mogućnosti razvoja čoveka, demokratskog stava o neophodnosti organizovanja škola, vaspitne funkcije škole, potrebe za kontinuiranim i permanentnim sistemom vaspitanja i obrazovanja, sistematskim metodičkim radom još u materinskoj školi, nastavnog procesa, osvetljavaju pedagoške horizonte jednakim sjajem kao i u društveno-istorijskom kontekstu vremena u kome je živio. I danas su ove ideje vrlo podsticajne, imaju svoje naslednike. Jan Amos Komenski uticao je na unapređenje vaspitne i obrazovne delatnosti, na razvoj pedagoške nauke. Svojim vizionarskim pedagoškim radom postavio je temelje pedagoške futurologije.

\section{SOCIAL - HISTORICAL CONTEXT, SCIENTIFIC ACHIEVEMENTS AND RE- LEVANCE OF SCHOOL AND TEACHING PROCESS OF JOHN AMOS COME- NIUS}

\section{Abstract}

The pedagogical legacy regards John Amos Comenius as one of the most important scholars in the field of pedagogy. While he was criticized at the time when he lived 
because of the views and beliefs he weaved in his works, he is regarded as a scholar of his day who acted with pedagogical passion in the fields of theory and practice of upbringing and education. The renaissance-style way of thinking was highlighted in the pedagogical ideas of Comenius who promoted abandonment of one-sidedness of old scholasticism and education of people for the Heavenly and for the Earthly Kingdoms. Wishing to overcome the intellectual one-sidedness of the old school, his pansophic concept of upbringing and education contributed to better quality acquisition of knowledge, adoption of skills and habits. The new school wants to implement the scientific knowledge in the educational process, encourage activity and self-activity of students.

The aim of our paper is to point out the scientific achievements and topicality of the school and teaching process of Comenius. The method of theoretical analysis and the historical method with the content analysis technique are applied for the purposes of this paper. The studying of primary and secondary sources suggests explicitly, owing to the methods applied, that the work of Comenius was and has remained the subject of studies and research due to a handful of useful ideas, thoughts, advices and instructions the work of today's teachers and practitioners is based on. In addition to his epochal work The Great Didactic, his book Orbis Sensualium Pictus also suggests the necessity of linking sensory impressions with students' activities. It represents a sort of a textbook for teachers providing the students with the possibility to efficiently adopt teaching contents in innovative way.

In conclusion, the authors point out that in the past there was always found a part of modernity that concerns Comenius and his knowledge.

Key words: pedagogical realism, pansophic concept of education, school and teaching processes.

\section{Literatura}

Avdijev, V. I. (1952). Istorija starog istoka. Beograd: Štamparsko preduzeće Rad.

Branković, D. i Ilić, M. (2011). Uvod u pedagogiju i didaktiku. Banja Luka: Comesgrafika.

Cenić, S. i Petrović, J. (2012). Vaspitanje kroz istorijske epohe. Vranje: Univerzitet u Nišu. Učiteljski fakultet u Vranju.

Cipro, M. (1991). Jan Amos Komenský. Prameny výchovy - sv. I.- Praha.

Čuma, A. (1991). Jana Amosa Komenského Orbis pictus stále aktuálny. Pedagogika, XLI(5-6), 603-609.

Despotović, P. (1902). Istoriska pedagogika. Beograd: Izdanje Dvorske Knjižarnice Mike Stajića.

Dobinson, C. H. (1970). Comenius and Contemporary Education. Hamburg: UNES$\mathrm{CO}$ Institute for Education. 
Glenn, J. L. (2018). The intellectual-theological leadership of John Amos Comenius. Perichoresis, 16(3), 45-61.

Gundem, B. (1992). "Vivat Comenius": A Ĉmmemorative esay on Johann Amos Comenius, 1592-1670. Journal of Curriculum and Supervision, 8(1), 43-55.

Ilić, M. i Mihajlović, T. (2016). Istorija nacionalne pedagogije. Banja Luka: Comesgrafika d.o.o. Banja Luka.

Jenjić, S. i Dragić, Ž. (2017). Prilozi metodici nastave prirode i društva. Banja Luka: Filozofski fakultet.

Jůvová, A. \& Bakker, F. (2015). Didactic Principles by Comenius and 21st Century Skills. Pedagogium 2, 7-19.

Kačapor, S. (2003). Sadržaji iz opšte istorije pedagogije. Pančevo: Grafos internacional.

Kamenov, E. (2006). Vaspitanje predškolske dece. Beograd: Zavod za udžbenike i nastavna sredstva.

Komenského, J. A. (1932). Orbis Pictus (Svět v obrazích). Preveo Jovan M. Popović. Beograd: Izdavač - Knjižarnica Gece Kona.

Komenski, J. A. (1946). Materinska škola. Beograd: Prosveta.

Komenski, J. A. (1954). Velika didaktika. Beograd: Savez pedagoških društava Jugoslavije.

Komenski, J. A. (1997). Velika didaktika. Beograd: Zavod za udžbenike i nastavna sredstva.

Lang, I. (1965). A Comparative Study of the Philosophies of John Amos Comenius and Maria Montessori on the Education of Children. Retrieved December 112019 from https://ecommons.luc.edu/cgi/viewcontent.

Lukaž, M. \& Munjiza, E. (2014). Education System of John Amos Comenius and its Implications in Modern Didactics. Život i škola, 60(31), 32-42.

Maksimović, J., Osmanović, J. i Milanović, A. (2018). Jan Amos Komeński w epoce współczesności. Odczytania - kontynuacje - krytyk. Siedleckie Zeszyty Komeniologiczne, $\mathrm{V}, 105-119$.

Maviglia, D. (2016). The Main Principles of Modern Pedagogy in 'Didactica Magna' of John Amos Comenius. Creative Approaches to Research, 9(1), 57.

Мединский, Е. Х. (1947). История педагогики. Москва: Просвещение.

Mihajlović, T. (2014). Aktuelnost shvatanja pedagoga klasika o porodičnom vaspitanju na ranom uzrastu. Norma, 1, 41-53.

Mihajlović, T. (2019). Tokovi i perspektive reformi škole, nastave i vaspitanja. U S. Marinković (Ur.), Nauka, nastava i učenje - problemi i perspektive (str. 115132). Užice: Pedagoški fakultet.

Piaget, J. (1993). Jan Amos Comenius (1592-1670). UNESCO, International Bureau of Education, 23(1-2), 173-196.

Spevak, Z. (2003). Jan Amos Komenski pedagog i utopista. Bački Petrovac: Kultura. Novi Sad: Fors. 
Stroope, M.W. (2005). The Legacy of John Amos Comenius. International Bulletin of Missionary Research, 29(4), 204-208.

Tešić, V. (1970). Savremenost i aktuelnost pedagoškog mišljenja Jana Amosa Komenskog. Nastava i vaspitanje, 1, 1-11.

Vlahović, B. (2001). Putevi inovacija u obrazovanju. Beograd: Eduka.

Vučinić, D. (2011). Shvatanja pedagoških klasika o prirodi, ulozi i značenju interesovanja učenika. Pedagogija, $L X V(4), 694-699$.

Vukasović, A. (1986). Utjecaj J. A. Komenskog na pedagoška i kulturna stremljenja u Hrvatskoj. Prilozi, 12(1-2), 163-175.

Vukasović, A. (2003). Odgojne vrijednosti i putokazi J. A. Komenskog za trećetisućljeće. Obnovljeni život, 58(1), 87-98.

Zaninović, M. (1988). Opća povijest pedagogije. Zagreb: Školska knjiga.

Žlebnik, L. (1970). Opšta istorija školstva i pedagoških ideja. Beograd: Naučna knjiga. 
T. V. Mihajlović, S. V. Jenjić: DRUŠTVENO-ISTORIJSKI KONTEKST, NAUČNI DOMETI I ...

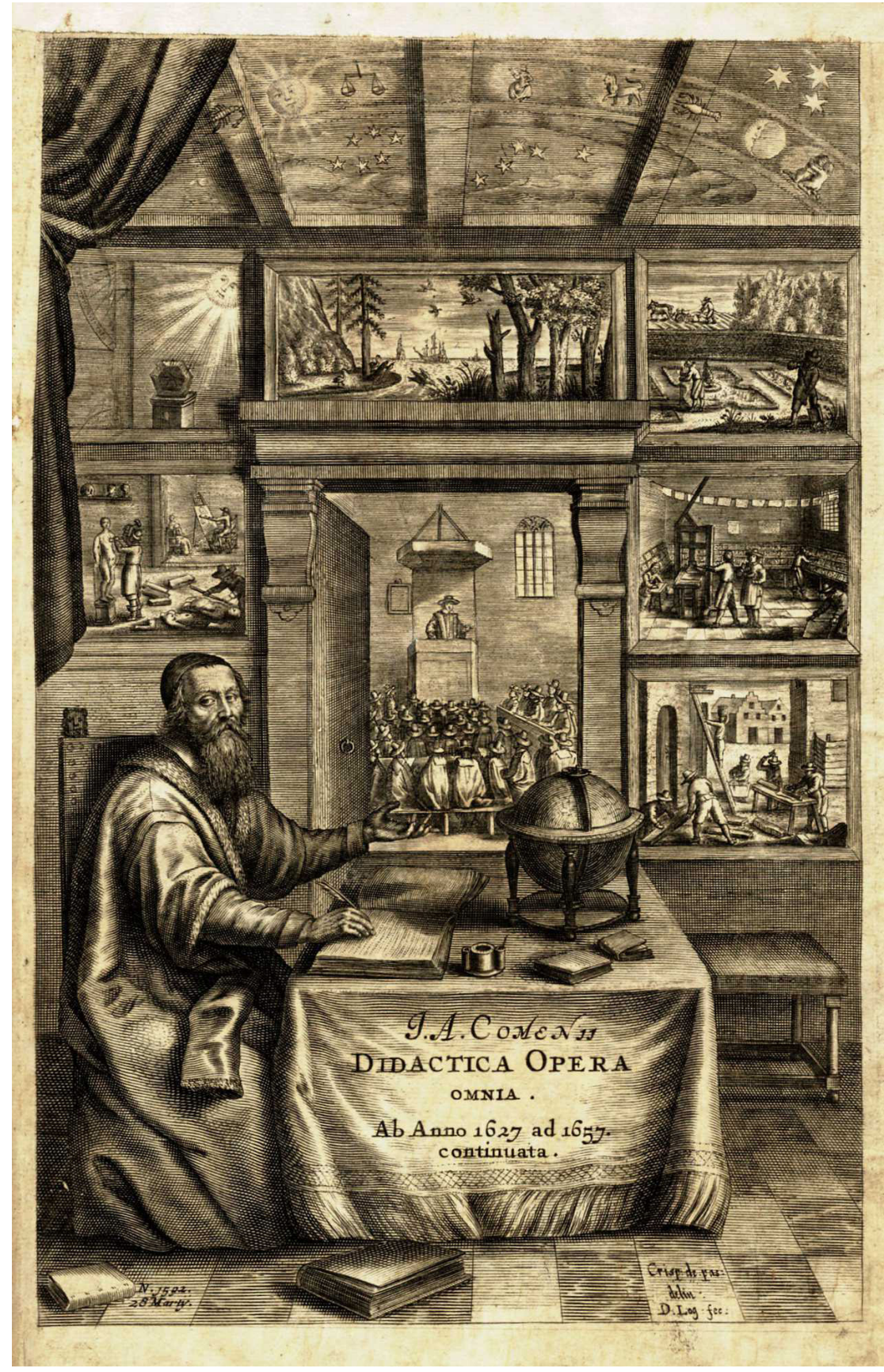

Comenius, Johann Amos: Opera didactica omnia. - Amsterdam, 1657.god. 